\author{
Martyna Kropiewnicka*, \\ Dariusz Ostrowiecki*
}

\title{
Administrative and civil liability for damage caused by the impact on the environment
}

\author{
http://dx.doi.org/10.12775/PYEL.2013.005
}

\section{Abstract}

This article is aimed at showing, through the analysis of specific elements of legal liability, which type of liability dominates in regulations referred to preventing and repairing damage in the environment: Directive 2004/35/ EC of the European Parliament and of the Council of 21 April 2004 on liability for environment in relation to preventing and remedying damage caused in the natural environment, the Act on Preventing Damages in the Environment and their Repair of 13 April 2007 and the Environmental 
Protection Act of 27 April 2001. This article shows that indicated acts include both elements of civil liability and administrative liability and it specifies place and role in the law of the civil and administrative liability for damage caused to the environment, and also compares these legal institutions in the context of environmental protection.

The authors of the article begin the analysis of topic by defining the term 'damages' in the civil law, and in the Act on Damages, then they refer to the definition of 'environmental damage' and finally compare the meaning of these two definitions. Through the analysis of these terms they try to answer the question, what is the legal character of damages in the environmental law, and if damages should have administrative meaning because of public character of the interest protected by the investigation of damage compensation. Moreover, the authors try to define the term 'legal liability' and they consider which type of legal liability is the liability for environmental damages, and which opinion dominates in the doctrine. Besides, the article focuses on the issue that the rule of guilt should give way to forms of liability based on objective criteria and comparing this with the predominant in the classical structure meaning of the damage in civil understanding the rule of the wrongful actions. The article presents the functions of legal liability in environmental protection and indicates which function dominates in specific type of legal liability refers to liability for environmental damages, at the same time, conditioning, as it were, the character of this liability. Subsequently, the authors make an analysis of procedure for pursing claims in matters relating to liability for environmental damage, e.g. which authorities are competent to make decisions and in what mode they take action. Authors also specify damage compensation measures that entitle to certain parties and make a conclusion if these measures have civil or administrative character. Refers to that, they describe the legal institution called 'ecological compensation'.

To sum up, the article focuses on specifying term limits for administrative and civil liability in legal regulations concerning protection of the environment and shows what led to the legislation that created existing regulations which cause plenty of dilemmas and controversies and have a complicated legal construction.

\section{Keywords}

Administrative liability, civil liability, types of liability, environmental damage, environmental protection, law. 


\section{The genesis of legal regulations in the field of liability for environmental damage}

In recent years the trend to the creation of legal regulations at the interface between civil and administrative law in the field of liability for dangerous and harmful action on the natural environment is observable in the European law, and consistently also in Polish. The evidence of this is the implementation of the Act of 13 April 2007 on Preventing Damages in the Environment and their Repair ${ }^{1}$ (further referred to as the Act on Damages), which shall implement the assumptions of the directive 2004/35/EC of the European Parliament and of the Council of 21 April 2004 on Liability for the Environment in Relation to Preventing and Remedying of Damage Caused in the Natural Environment ${ }^{2}$. Indicated acts were enacted because of the need to meet growing demands for the protection of the dynamically changing environment. On the basis of these legal acts, their controversial and raising concern issues, it is to determine what type of responsibility we are dealing with ${ }^{3}$. This aim of this article is to show the place and role in the law of civil and administrative liability for damages caused to the environment, and to compare these legal institutions in the context of environmental protection. The law on preventing damages in the environment and their repair was created as a result of growing needs for environmental protection, caused by dynamic economic development and rapid civilization jump, which took place in the second half of 20th century. Industrialization of life has caused a threat to existing natural resources fauna, flora, water, air, etc. and at the same time to human health. So, there was a worldwide trend to educate society that the environment is a common good and not only countries, through their authorities, should take care of their resources, but every citizen through individual and joint actions or by refraining from negative behaviour, may take care of the surrounding

1 Act of 13 April 2007, on preventing damages to the environment and their repairing, Journal of Laws, No 75, item 493 with amendments.

2 OJ L No 143, p. 56; further referred to as: the Directive 2004/35/EC.

3 E.K. Czech, Spór wokót odpowiedzialności za szkodę w środowisku (Dyrektywa 2004/35/ WE), PiP No 1/2007, p. 55. 
environment ${ }^{4}$. Certainly, the broadening of liability for damages caused by the environmental impact of civil liability elements gives more opportunities to realize this vision. It also imposes the order for a specific behaviour on an individually designated legal entity.

\section{The concept of environmental damage}

The analysis of this topic should begin by defining the term 'damages' in civil law, and in this Act. The damage within the meaning of civil law is any harm to legally protected goods, which the victim has suffered from, against their will ${ }^{5}$. There are two main types of damages: damage to property and personal injury. Damage to property refers to detriment, which relates directly to the injury to property, and the term personal injury is directly related to the injured, it is the result of the breach of personal rights of injured and indirectly, it can also be expressed in financial consequences. Examples of damage to property are damages caused by water, air and ground pollution e.g. fish sewage poisoning or damage to crops due to emissions of air pollutants ${ }^{6}$. Contrary, personal injuries include respiratory diseases caused by air pollution. Damage to property or personal injury is a damage in terms of purely civil law, because on one side we have the perpetrator of the damage liable to compensate it, and on the other side, individualized legal entity to which the rule of law grants a claim for compensation, which demonstrates the protection of their individual interest. In environmental law the implementation of such claim is naturally not excluded, however, in addition to the damage defined this way there is also another understanding. Even before the Act on Damages was implemented, 'environmental damage' could be found in legal language, otherwise known as 'ecological damage', which was equivalent to negative consequences of impact on the environment ${ }^{7}$. Although this term is still functioning, it has not developed

4 B. Draniewicz, Odpowiedzialnośc za szkode w środowisku w ustawie o zapobieganiu szkodom w śodowisku $i$ ich naprawie - wybrane zagadnienia, MP No 5/2008, www. monitorprawniczy.pl

5 H. Witczak, A. Kawałko, Zobowiqzania, Warszawa 2008, p. 40

6 W. Radecki, Odpowiedzialność prawna w ochronie środowiska, Warszawa 2002, p. 90.

7 A.Wasilewski, Wspólnotowe ramyodpowiedzialności majątkowej za „szkody środowiskowe" (w:) Rozprawy prawnicze. Księga pamiątkowa Profesora Maksymiliana Pazdana, Kraków 2005, p. 743-756. 
its full definition yet ${ }^{8}$. Upon entry into force the Act on Damages, it has been concluded that the concept of environmental damage can be used interchangeably with the term 'environmental damage' or 'ecological damage'. The definition of environmental damage found in article 6 section 11 of the Act on Damages, which states that damage to the environment is 'a negative, measurable change in state or function of the natural elements, evaluated in relation to the initial state, which has been caused directly or indirectly by the activities carried out by the user of environment(...)'.In the presented definition it is clear that the damage does not apply to individually designated legal entity, but it is a change concerning the components of the environment. The Act was not in fact, according to the assumptions of the Directive 2004/35/ $\mathrm{EC}$, to protect individual interest, and its purpose is primarily to prevent the damages occurring outside of subjective rights. An exception to this rule is article 18 of the Act on Damages, which provides legal protection for the owner of the land for damages which occurred as a result of certain actions of 'the user of the environment' and which caused the damage. Also in the Environmental Protection Act ${ }^{10}$ (further referred to as the EPA), the protection for injured entity by the detrimental actions to the environment is mentioned, as indicated by article 323 section 1: 'Anyone, who is at risk of a loss or suffered a loss as a result of illegal impact on the environment, may demand from the person responsible for this threat or damage to restore the condition compliant with the provisions of law and to undertake preventive measures (...) '. This stems from the fact that the damage caused to the environment does not preclude the simultaneous damage to property or personal injury. The law must therefore foresee such situations. Of course, it does not preclude the claims under the Civil Code ${ }^{11}$. The aim of the Act on Damages is not to replace existing regulations, but to develop and complete them ${ }^{12}$. But the problem arises how to qualify the negative impact on environmental components, which are things that do not belong to anyone or are not things within the meaning of the Civil Code. In such a case we do not manage them with individual victim ${ }^{13}$. However, it is worth

\footnotetext{
W. Brzeziński, Ochrona prawna naturalnego środowiska cztowieka, Warszawa 1975, p. 5.

E.K. Czech, op.cit., p.64.

10 Act of 27 April 2001 on Environmental Protection Law, consolidated text, Journal of Laws, No 178, item 1060.

11 Act of 23 April 1964 Civil Code, Journal of Laws, No 16, item 93, with amendments.

12 B. Draniewicz, Odpowiedzialność za szkodę w środowisku... op.cit. 
paying attention to article 232 section 2 of the EPA, where the term 'the environment as a common good' is used. If it is endangered or violated, then the State Treasury, local government unit, as well as environmental organizations may lay the claim. In relation to the Code regulations, we have then the extension of a catalogue of available legal remedies available, e.g. a claim for an injunction is granted not only to the owner, but anyone who has the right to things, the claim can be pursued even if there had been no breach of individual rights and responsible is not only the one who runs a business, but also the one who actually benefits from it, without making any illegal impact on the environment ${ }^{14}$. From the analysis of the Act, it can be concluded that the damage to the environment should be considered as injury within the meaning of administrative law, because the interest protected by the investigation of damage compensation has undoubtedly public character and is not intended to compensate the damages incurred by a specified entity. In order to determine the liability and the causes of its emergence is mainly to determine the existing state of the environment objectively. This liability does not run because of the existence of liability or committing an unlawful act ${ }^{15}$. Also the doctrine representatives are in favour of the fact that in the field of environmental protection, interests of an individual accumulate into the public interest and in fact these two issues are treated almost inseparable, because the damage caused to the environment, regardless of whether or not it is connected to damage in legal entity's goods, almost always causes damage to the common good ${ }^{16}$.

\section{Concept and type of legal liability for environmental damages}

The term 'liability' is not only a strictly legal category. We can also talk about it in ethics, philosophy and psychology. It involves certain moral principles, to a more or lesser extent implemented by the community. Generally speaking, the liability can be considered in connection with the

14 J. J. Skoczylas, Odpowiedzialnosé cywilna na podstawie ustawy - prawo ochrony środowiska, PS No 4/2003, p. 68.

15 J. Boć, K. Nowacki, E. Samborska-Boć, Ocbrona środowiska, Łódź 2004, p. 387.

16 Ibidem. 
performance of a specific obligation. It should be understood as a specific form of the settlement of its execution. The obligation is broadly understood - in both an action (active behaviour in specific situations) and omission (the entity that was required to take specified action) ${ }^{17}$.

By the term 'legal liability' incurring negative consequences of the events by an entity causing the even, stipulated by the law, should be understood. It is based on legal norms, which indicate a duty and a settlement of its implementation. According to W. Lang, liability in its classic sense is incurring by a specified entity, the negative consequences stipulated by law, for conditions or events which are subject to negative normative qualifications. They are assigned to the entity in specified facts of the case and legal order ${ }^{18}$. The most common division of liability for environmental damage is the division according to the branches of law criterion. We can distinguish criminal, civil or administrative liability. If we take into consideration the nature of the legal norm the liability is based on, we can as well identify the employee liability ${ }^{19}$. The authors of this analysis want to focus only on the last two. Thus, another analysed issue is which type of liability is the liability for environmental damage. We need to take into account the fact that nature has its own laws, and man's impact on its functioning is not absolute, often quite limited. In many cases it is difficult to determine with sufficient precision the causes of events causing damages ${ }^{20}$. Comparing it with the predominant in the classical structure meaning of the damage in civil understanding the rule of the wrongful actions, academic writers are inclined to the idea that in the cases of environmental damages, the rule of guilt should give way to forms of liability based on objective criteria, without reference to the legal concept of guilt. In support of this view, the representatives of science argue that the risk of damages related to activities posing damages to the environment, the person who undertakes such activities for personal benefits should be charged ${ }^{21}$. What is more, responsibility does not exclude the fact that the activity that causes the

17 M. Górski, Odpowiedzialnośc administracyjnoprawna w ochronie środowiska, Warszawa 2008, p. 11.

18 W. Lang, Struktura odpowiedzialności prawnej, Zeszyty naukowe UMK, z. 31 - Prawo VIII, Toruń 1968, p.12.

19 M. Górski, Odpowiedzialność administracyjnoprawna w ochronie środowiska, Warszawa 2008, p. 12.

20 B. Draniewicz,, Odpowiedzialność za szkodę w środowisku..., op.cit.

21 W. Czachórski, Zobowiązania. Zarys wyktadu, Warszawa 1998, p. 180. 
damage shall be carried out on the basis of the decision and its limits. The legislature has expressed that even before the entry into force the article 325 of the EPA. The Act on Damages subsequent entry into force of the Act on Damages confirmed the direction of the legislature, and reflected the implementation of the 'polluter-pays' principle. Its sources can be interpret already in the recommendations of the Organization for Economic Cooperation and Development of 14 November 1974 and recommendations of the Council 75/436/EEC ${ }^{22}$. Although they had a non-binding character, they showed that natural or legal persons who were responsible for causing environmental damages should bear the costs associated with their removal. Upon mentioned rule was also contained in article 174 of the Treaty of Rome, which imposed a duty to cover the environmental damage costs by the person who committed them ${ }^{23}$. According to the interpretation of point 2 of the Preamble to Directive 2004/35/EC subject incriminated for carrying damage to the natural environment by his conduct, is an operator' understood as a natural or legal person, private or public person who operates or controls the occupational activity, or if this follows from the laws of that state, a person is delegated to make the economic decisions related to the technical functioning of such activity ${ }^{24}$.

The Polish legislator who follows the European countries tracks, implementing to our law the rule discussed in the article 7 section 1 of the $\mathrm{EPA}$, in an identical manner, has imposed the obligation to bear the costs of pollution through 'entities using the environment'. In this concept, in accordance with article 6 section 9 of the Act on Damages, should be understand:

- An entrepreneur within the meaning of the Act of 19 November 1999 of Business Law (now the Act of 2 July 2004, Freedom of Economic Activity $^{25}$ ) and a person conducting manufacturing activities in agriculture, in agricultural crops, farming or animal husbandry, vegetable growing, horticulture, forestry and fishery and the person conducting the medical profession;

22 Decyzje, zalecenia i inne instrumenty prawne OECD, t. II: Zalecenia, Warszawa 1997, segregator II, point 9.1 .

${ }_{23}$ K. Gruszecki, Prawo Ochrony Środowiska, Komentarz, Warszawa 2008, p. 36-37.

24 B. Draniewicz, Odpowiedzialnośc za szkodę w środowisku... op.cit.

25 Act of 2 July 2004, Freedom of economic activity, Journal of Laws, No 101, item 1178, with amendments. 
- A natural person referred to above, using the environment in so far as the license requires;

-- An organizational unit not an entrepreneur ${ }^{26}$.

It should be noted that for these entities to be held liable, they must conduct a business activity that creates the risk of causing damage to the environment or other activity that results in direct threat of injury or damage to the environment. Article 3 Act on Damages has enumerative catalogue of activities posing a risk of environmental damage ${ }^{27}$.

So we can say that this obligation applies to both natural persons and legal entities. In practice, the 'polluter pays' rule, is realized through economic instruments such as charges for use of the environment or penalties related to its pollution ${ }^{28}$. The condition here is the ability to identify the perpetrator. The liability institution for dangerous and harmful to the environment actions is therefore certainly heterogeneous. On the one hand, it is a clear tendency for such liability to have objective character, so depart from classical civil law liability concept, on the other hand, regulations guiding the rule to impose on the individually marked damages offender with the appropriate distress, instead of paying of the damages from public funds.

In the light of article 12 section 1 of the EPA, in conclusion it should be noted that the view according to which the liability as provided for in the Act on Damages has administrative liability character, is dominant in the doctrine ${ }^{29}$. Quite inspiring, but too far-reaching view to the above ${ }^{30}$ is adding to the Act the hybrid traits, where in fact we are dealing with administrative liability - what to implement, and civil liability - as to the content. The difficulty in determining the nature of liability may be associated with the fact that liability is enforced through measures that are characteristic for administrative law ${ }^{31}$. Arguments in favour of the fact that

26 B. Draniewicz, Odpowiedzialność za szkodę w środowisku... op.cit.

27 Ibidem.

28 K. Gruszecki, Prawo Ochrony Środowiska, Komentarz, Warszawa 2008r., p. 36-37.

29 Tak m.in.M.M.Koening-Witkowska, Prawo środowiska Unii Europejskiej. Zagadnienia Systemowe, Warszawa 2005, s. 245, J. Jednorośka, Prawo ochrony środowiska, Podręcznik, Wrocław 2005, p.487.

30 W. Radecki Komentarz

31 Ibidem, p. 16. 
liability for environmental damages has administrative character can be inferred primarily from the following circumstances ${ }^{32}$ :

a) the relations between the entity benefiting from the environment and the public body;

b) the good is the protected environment, which is a public good;

c) there do not exist the same important entities in terms of rights and status;

d) the execution of duties is based on the provisions on enforcement in the administration;

e) regulations in order to the Directive $2004 / 35 / \mathrm{EC}^{33}$.

It should be emphasized that disputes about the character of liabilities arising from the same directive, because the administrative liability was regulated there in vague and unclear manner.

However, from the regulation contained in article 322 of the EPA, it must be concluded that in relation to the damage caused effecting on environment, through the rule, the provisions of the Civil Code are used. The civil law environment protection measures, which are regulated by the Code rules can be divided into two categories:

1) forming grounds to compensation,

2) forming grounds to the restitution claim.

The first one has more preventive character, is to directly prevent damages, the second one allows you to file a complaint for an injunction against the person infringing property such as the emission of gases, dust ${ }^{34}$.

It should be also emphasized that, in accordance with article 12 section 1 of the Act on Damages, when the damage or its threat has been committed by more than one entity using the environment, their liability will have joint and several character. This institution associates with passive joint and several liability, arising out from Article $366 \S 1$ of the Civil Code. Thus, one might conclude that the civil liability may also be applicable in the context of environmental law ${ }^{35}$.

T. Czech, Wina jako przestanka odpowiedzialności administracyjnoprawnej za szkode w środowisku, PPP 2009, No 2 p. 22-23.

33 L. Bergkamp, The Proposed EC Enviromental Liability Regime and EC Law Principles, Enviromental Liability Law Review 2001, p. 255.

34 M. Górski, Odpowiedzialnośc administracyjnoprawna w ochronie środowiska, Warszawa 2008, p. 15.

35 B. Draniewicz, Odpowiedzialność za szkodę w środowisku... op.cit. 


\section{The functions of legal liability in environmental protection}

In the light of current legislation, there are four basic functions of legal liability. We can include functions mentioned below:

a) educational (prevention), the purpose is to prevent the damage to the environment (e.g. by issuing an administrative decision that orders to take specific preventive measures);

b) repressive, its purpose is to punish the person who committed the actions that cause damage to the environment (primarily refers to criminal liability);

c) compensation, which aims to restitution through compensation so as to 'equalize' negative effects of damage caused to the environment ${ }^{36}$;

d) restitution - to restore the original state, in its strict sense ${ }^{37}$.

It should be emphasized that all the above functions are present in each type of liability for damage to the environment mentioned above. However, it is noteworthy that in the case of civil liability compensation function is dominant. Although it is the least desirable in environmental protection it is really necessary ${ }^{38}$. It occurs after the violation and is intended to compensate, if the restoration to its original state, for various reasons, it is not possible. An example of this is an entity that made the illegal felling of trees. They can not restore that to the previous state, only compensate for the damage, e.g. by paying a fine or planting new plants. Preventive function is also of some importance, at a minimum as a function of repression. The first is to prevent damages to the environment, both in the present and future. The second one is used to punish the person responsible for the committed infringement. Function of restitution is quite as important. It has successive character. Its aim is to restore the previous state. Contrary to the position and shape of individual features in the administrative liability. At the forefront is the preventive function (for example, administrative decisions may withhold actions violating the requirements of environmental protection),

36 Prof. J. Machowski, Ochrona środowiska. Prawo i zrównoważony rozwój, Warszawa 2003, p. 121-122.

37 B. Wierzbowski, B. Rakoczy, Prawo ochrony środowiska, zagadnienia podstawowe, Warszawa 2010, p.107.

38 Ibidem, s. 108. 
as well compensatory function is important (implemented by means of fines for the damage done, intended for projects which aims are to improve and to increase environmental protection) ${ }^{39}$. It is worth emphasizing that despite different types of liability for damage caused to the environment the assertion that the functions performed in the abstract way, in fact to achieve identical goal which is protection and maintenance of the best possible state of the environment, seems to be undisputed. It can be also assumed that by using administrative instruments, in particular cases we obtain effects consistent to the use of the civil liability instruments ${ }^{40}$.

\section{Procedure for pursing claims}

To solve complex problems determining the limits of administrative and civil liability for damage caused to the environment the method of solving the conflict should be defined ${ }^{41}$. In the first place one should pay attention that the authorities competent to decide matters relating to liability for environmental damage are public administration bodies - regional directors for environmental protection or the minister responsible for the environment. Their task is to identify the person responsible for that damage or imminent threat thereof and the measures to be taken by the offender to repair the damage. Those authorities shall take action with the office and they, within their competence make a determination of liability. It occurs through the expression of an authoritarian and unilateral ${ }^{42}$. So one can clearly see that this procedure differs from civil procedure, in which plaintiff alone defines the size of damage and the procedure is initiated on their own initiative. Matters relating to environmental protection are therefore governed by administrative law, which is also characterized by less formality and greater speed than in civil proceedings ${ }^{43}$. Probably, the legislator adopted a regulation of the procedure due to the fact that the environment is a common good

39 E.K. Czech, Spór wokót odpowiedzialności za szkodę w śodowisku (Dyrektywa 2004/35/ WE), PiP No 1/2007, p. 58.

40 A. Lipiński, Prawne podstawy ochrony środowiska, Kraków 2002, p. 315.

41 J. Łętowski, Prawo administracyjne. Zagadnienia podstawowe, Warszawa 1990, p. 21.

42 J. Boć, K. Nowacki, E. Samborska-Boć, op.cit., p. 388.

43 Ibidem, sb. 106. 
that requires continuous protection and hazard authorities must respond quickly to adverse changes in the environment and lead to the quickest possible improvement of his condition.

\section{Damage compensation measures}

This leads to the question of damages, which slightly differ from those laid down in civil law. The entity has to carry out some preventive or corrective actions (article 9 of the Act on Damages). It is true that under the administrative responsibility defined in the EPA, reducing the environmental impact or restoring the environment to its proper state (article 362 section 1 of the EPA) is specific to an institution called 'ecological compensation' or 'ecological exemplary damage' ${ }^{44}$, regulated by article 362 section 3 of the EPA, which requires the debtor to pay damages to the budgets of relevant public authorities, i.e. a sum of money equivalent to the amount of damages resulting from damages made to the environment, but the doctrine of the law is assigned to the quasi-compensation, awarded to traditional means of redress. On the basis of the Law on Environmental Protection and Management of $1980^{45}$, representatives of the doctrine preached the idea that the designated amount of money is the cash compensation for nonpecuniary damage in the social values of the environment as a surrogate for natural restoration. This understanding of the concept functions until now $^{46}$. Another manifestation of administrative responsibility is the fact that public administration in any decision imposing preventive or corrective measures must accurately identify the legal basis for their actions, and these decisions must meet the requirements, which in the legal system are mandatory components of administrative decisions ${ }^{47}$.

44 A. Lipiński (w:) Ustawa - Prawo ochrony środowiska. Komentarz, pod red. J. Jendrośki, Wrocław 2001 p. 867

45 Journal of Laws, No 3, item. 6 with amendments.

46 G. Domański, Sankcje majątkowe $i$ optaty za zanieczyszczenie środowiska w świetle nowej ustawy, Pal. No 6/1980, p. 28.

47 E.K. Czech, op.cit., p.61. 


\section{Conclusions}

Finally, one must consider what led to the European legislation that created the existing Act on Damages today and connected two branches of law in a specific way. First of all, it must be emphasized that it is difficult to separate administrative law from civil law. Further considerations cause much more dilemmas and controversies. Environmental protection is a peculiar field of life, which involves most of the responsibility of private law for the good that is public.

One may argue that individual interests of both laws are inherent in the public interest here. Certainly, civil and administrative liability have common points, such as the functions and purpose of that responsibility, because their main objective is prevention and recovery, provided that in liability function gives the role of compensatory restitution, which results from the specific legal relations linking actors of civil law. The views on this issue, however, are still divided, leading to even more discussion on the merger of these legal institutions ${ }^{48}$. It is certain, however, that both lead to the same accountability results, namely the maintenance of the environment in an intact, the best possible condition.

Summarising, the term limits for administrative and civil liability in the legal regulations concerning the protection of the environment is extremely difficult, and despite the end of the four-years period since the issue of the Act on Damages, they still control what is widely considered ambiguous and controversial issue. The Act on Damages does not create a new liability regime for environmental protection, while enriching the already existing, but due to the complex structures it contains, its incorporation into the existing legal system is a major challenge for applying the law, and also comes on the side of the representatives of scientific institutions need thorough consideration contained in the Act.

It should be noted that administrative liability is in close correlation with civil liability. It must be emphasised that the latter is characterized by the lowest degree of direct state coercion. There is the freedom to shape

B. Wierzbowski, B. Rakoczy, Podstawy prawa ochrony środowiska, Warszawa 2005, s. 105, por. A. Lipiński, Prawne podstawy ochrony środowiska, Kraków 2002, p. 315. 
legal relationships between the parties ${ }^{49}$. In fact, the initiation of any proceedings on the basis of civil liability associated with the activity of the entity, which applies damage to the environment directly. Civil liability is in fact designed to protect the rights of individuals without reference from the public interest.

In the case of administrative liability, the proceedings may be instituted ex officio, by a competent administrative authority. We can conclude that protection is provided for the public dimension, whose main goal is the protectionism going in the direction of the general good.

Although defining limits and mutual relations of administrative and civil liability is far from difficult, it should be strongly emphasized that apart from all the differences arising from the kind of responsibility, these regimes through the implementation of various functions, aim for the same purpose, namely to support the protection of environment and behaviour in the most optimum condition of natural areas.

49 J. Skoczylas, Pojęcie i rodzaje odpowiedzialności prawnej w ochronie środowiska, Zeszyty Naukowe SGSP, nr 41/2011, p. 119. 